\title{
Ratios of Co/Trace Elements As Prostate Cancer Markers
}

Vladimir Zaichick1*, Sofia Zaichick2

${ }^{1}$ Radionuclide Diagnostics Department Medical Radiological Research Centre Korolyev St.- 4, Obninsk 249036 Kaluga Region, Russia ${ }^{2}$ Laboratory of Dr. Gabriela Caraveo PisoFeinberg School of Medicine Northwestern University 303 East Chicago Avenue, Ward 10-144 Chicago, IL 60611-4296, USA

*Corresponding Author: Dr.V. Zaichick, Radionuclide Diagnostics Department, Medical Radiological Research Centre, Obninsk 249036, RUSSIA, Fax: +7 (495) 956 1440, Phone: +7 (48439) 60289, E-mail: vezai@obninsk.com

Citation: Vladimir Zaichick et al. Ratios of cobalt/trace element contents in prostate gland as carcinoma's markers. Int J Cancer Epid \& Res.1:1, 21-27

Copyright: (C) 2017, Vladimir Zaichick et al. 2017, This is an open-access article distributed under the terms of the Creative Commons Attribution License, which permits unrestricted use, distribution, and reproduction in any medium, provided the original author and source are credited.

Received March 13, 2017; Accepted March 10, 2017; Published March 23, 2017.

\section{Abstract}

The aim of the study was to evaluate whether significant changes in the prostatic tissue levels of ratios $\mathrm{Co} /$ trace element contents exist in the malignantly transformed prostate. Contents of $\mathrm{Co}$ and other 42 trace elements ( $\mathrm{Ag}, \mathrm{Al}, \mathrm{Au}, \mathrm{B}, \mathrm{Be}, \mathrm{Bi}, \mathrm{Br}, \mathrm{Cd}, \mathrm{Ce}, \mathrm{Cr}, \mathrm{Cs}, \mathrm{Dy}, \mathrm{Er}, \mathrm{Fe}$, Gd, Hg, Ho, La, Li, Mn, Mo, Nb, Nd, Ni, Pb, Pr, Rb, Sb, Sc, Se, Sm, Sn, Tb, Th, Ti, Tl, Tm, U, Y, Yb, Zn, and Zr) in normal (N, n=37, age range 41-87 years), benign hypertrophic (BPH, $n=32$, age range 56-78), and cancerous human prostate (PCa, $n=60$, age range 4070) were investigated. Measurements of trace element contents were performed using a combination of instrumental neutron activation analysis and inductively coupled plasma mass spectrometry. Then the levels of ratios Co/trace element contents in every sample were calculated. It was observed that the ratio to $\mathrm{Co}$ of $\mathrm{Ag}, \mathrm{Al}, \mathrm{Au}, \mathrm{B}, \mathrm{Be}, \mathrm{Bi}, \mathrm{Br}, \mathrm{Ce}, \mathrm{Cr}$, $\mathrm{Dy}, \mathrm{Er}, \mathrm{Gd}, \mathrm{Ho}, \mathrm{La}, \mathrm{Li}, \mathrm{Mn}, \mathrm{Nd}, \mathrm{Ni}, \mathrm{Pb}, \mathrm{Pr}, \mathrm{Sb}$, $\mathrm{Sm}, \mathrm{Sn}, \mathrm{Tb}, \mathrm{Th}, \mathrm{Ti}, \mathrm{Tl}, \mathrm{U}, \mathrm{Y}$, and $\mathrm{Zr}$ mass fraction were significantly lower in cancerous tissues than in normal and $\mathrm{BPH}$ prostate. It was proposed to use the $\mathrm{Co} / \mathrm{Ag}, \mathrm{Co} / \mathrm{Al}, \mathrm{Co} / \mathrm{B}, \mathrm{Co} / \mathrm{Bi}, \mathrm{Co} / \mathrm{Li}, \mathrm{Co} / \mathrm{Mn}, \mathrm{Co} / \mathrm{Pr}, \mathrm{Co} / \mathrm{Th}, \mathrm{Co} / \mathrm{Tl}$, and $\mathrm{Co} / \mathrm{Zr}$ mass fraction ratios in a needle-biopsy core as an accurate tool to diagnose prostate cancer. Further studies on larger number of samples are required to confirm our findings and to investigate the impact of the trace element relationships on prostate cancer etiology.

Keywords: trace elements; trace element content ratios; prostate; benign prostatic hypertrophy; prostatic carcinoma; neutron activation analysis; inductively coupled plasma mass spectrometry

\section{Introduction}

The prostate gland may be a source of many health problems in men past middle age, the most common benign prostatic hyperplasia $(\mathrm{BPH})$, and prostatic carcinoma $(\mathrm{PCa})$. $\mathrm{BPH}$ is a noncancerous enlargement of the prostate gland leading to obstruction of the urethra and can significantly impair quality of life. The prevalence of histological BPH is found in approximately $50-60 \%$ of males age $40-50$ and greater than $90 \%$ of men over 70 years old [1, 2]. In many Western industrialized countries, including North America, $\mathrm{PCa}$ is the most frequently diagnosed form of noncutaneous malignancy in males. Except for lung cancer, $\mathrm{PCa}$ is the leading cause of death from cancer [3-8]. Although the etiology of BPH and $\mathrm{PCa}$ is unknown, some trace elements have been highlighted in the literature in relation to the development of these prostate diseases [9-29].

Trace elements have essential physiological functions such as maintenance and regulation of cell function and signalling, gene regulation, activation or inhibition of enzymatic reactions, neurotransmission, and regulation of membrane function. Essential or toxic (mutagenic, carcinogenic) properties of trace elements depend on tissue-specific need or tolerance, respectively [30]. Excessive accumulation, deficiency or an imbalance of the trace elements may disturb the cell functions and may result in cellular degeneration, death and malignant transformation [30].

In earlier reported studies [31-69] significant changes of trace element contents in hyperplastic and cancerous prostate in comparison with those in the normal prostatic tissue were observed. In particular, it was shown that the average mass fraction of some trace elements in BPH were higher than normal levels, while those in adenocarcinoma were lower than in healthy prostatic parenchyma $[60,61,66,67,68]$. Obtained results formed the basis for a new method for differential diagnosis of BPH and $\mathrm{PCa}$, the essence of which was to determine the ratios of chemical element contents changed in opposite directions during malignant transformation of prostate. For example, a significant informative 
value of $\mathrm{Zn} / \mathrm{Co}$ content as a tumor marker for PCa diagnostics was shown by us [70]. Hence it is possible that besides $\mathrm{Zn}$, the ratio of Co to other trace elements also can be used as tumor markers for distinguish between benign and malignant prostate.

Currently number of methods was applied for the measurement of chemical elements contents in samples of human tissue. Among these methods, the instrumental neutron activation analysis with high resolution spectrometry of long-lived radionuclides (INAALLR) is a non-destructive and one of the most sensitive techniques. It allows measure the chemical element contents in few milligrams tissue without any treatment of sample. Nondestructive method of analysis avoids the possibility of changing the content of trace elements in the studied samples [71-74], which allowed for the first time to obtain reliable results. However, INAA-LLR allows only determine the mean mass fractions of 10-11 trace elements in the samples of normal and cancerous prostate glands [15,28]. The inductively coupled plasma mass spectrometry (ICP-MS) is more power analytical tool than INAA-LLR [18], but sample digestion is a critical step in elemental analysis by this method. In the present study two these analytical methods were used and the results, obtained for some trace elements by ICP-MS, were under the control of INAA-LLR data.

The present study had three aims. The main objective was to obtain reliable results about the 43 trace elements: $\mathrm{Ag}, \mathrm{Al}, \mathrm{Au}, \mathrm{B}, \mathrm{Be}, \mathrm{Bi}$, $\mathrm{Br}, \mathrm{Cd}, \mathrm{Ce}, \mathrm{Co}, \mathrm{Cr}, \mathrm{Cs}$, Dy, Er, Fe, Gd, Hg, Ho, La, Li, Mn, Mo, $\mathrm{Nb}, \mathrm{Nd}, \mathrm{Ni}, \mathrm{Pb}, \mathrm{Pr}, \mathrm{Rb}, \mathrm{Sb}, \mathrm{Sc}, \mathrm{Se}, \mathrm{Sm}, \mathrm{Sn}, \mathrm{Tb}, \mathrm{Th}, \mathrm{Ti}, \mathrm{Tl}, \mathrm{Tm}, \mathrm{U}, \mathrm{Y}$, $\mathrm{Yb}, \mathrm{Zn}$, and $\mathrm{Zr}$ contents in intact prostate of healthy men aged over 40 years and also in the prostate gland of age-matched patients, who had either BPH or PCa, combining in consecutive order nondestructive INAA-LLR with destructive ICP-MS method. The second aim was to calculate $\mathrm{Co} /$ trace element content ratios for every samples and compare the levels of these ratios in normal, hyperplastic, and cancerous prostate. The third and final aim was to evaluate the ratios of $\mathrm{Co} /$ trace element contents for diagnosis of prostate cancer.

All studies were approved by the Ethical Committees of the Medical Radiological Research Centre, Obninsk.

\section{Material and Methods}

Samples

The patients studied $(n=92)$ were hospitalized in the Urological Department of the Medical Radiological Research Centre (Obninsk, Russia). All of them were European-Caucasian, citizens of Moscow and Obninsk (a small city in a non-industrial region $105 \mathrm{~km}$ south-west of Moscow). Transrectal puncture biopsy of suspicious indurated regions of the prostate was performed for every patient, to permit morphological study of prostatic tissue at these sites and to estimate their chemical element contents. In all cases the diagnosis has been confirmed by clinical and morphological results obtained during studies of biopsy and resected materials. The age of 32 patients with $\mathrm{BPH}$ ranged from 56 to 78 years, the mean being $66 \square 6$ (M $\square \mathrm{SD}$ ) years. The 60 patients aged 40-79 suffered from PCa (stage T1-T4). Their mean age was $65 \square 10$ (M $\square \mathrm{SD}$ ) years.

Intact prostates $(\mathrm{N})$ were removed at necropsy from 37 men aged 41-87 who had died suddenly. All deceased were EuropeanCaucasian, citizens of Moscow. Their mean age was 55 $\square 11$ (M $\square \mathrm{SD}$ ) years. The majority of deaths were due to trauma. Tissue samples were collected from the peripheral zone of dorsal and lateral lobes of their prostates, within 2 days of death and then the samples were divided into two portions. One was used for morphological study while the other was intended for chemical element analysis. A histological examination was used to control the age norm conformity, as well as to confirm the absence of microadenomatosis and latent cancer $[14,15,20,28]$.

\section{Sample preparation}

All tissue samples were divided into two portions. One was used for morphological study while the other was intended for trace element analysis. After the samples intended for trace element analysis were weighed, they were freeze-dried and homogenized. The sample weighing about $10 \mathrm{mg}$ (for biopsy materials) and 50-100 mg (for resected materials) was used for trace element measurement by INAA-LLR. The samples for INAA-LLR were wrapped separately in a high-purity aluminum foil washed with double rectified alcohol beforehand and placed in a nitric acidwashed quartz ampoule.

After INAA-LLR investigation, the prostate samples were taken out and used for ICP-MS method. The samples were decomposed in autoclaves; $1.5 \mathrm{~mL}$ of concentrated $\mathrm{HNO} 3$ (nitric acid at $65 \%$, maximum (max) of $0.0000005 \% \mathrm{Hg}$; GR, ISO, Merck) and $0.3 \mathrm{~mL}$ of $\mathrm{H} 2 \mathrm{O} 2$ (pure for analysis) were added to prostate tissue samples, placed in one-chamber autoclaves (Ancon-AT2, Ltd., Russia) and then heated for $3 \mathrm{~h}$ at $160-200{ }^{\circ} \mathrm{C}$. After autoclaving, they were cooled to room temperature and solutions from the decomposed samples were diluted with deionized water (up to $20 \mathrm{~mL}$ ) and transferred to the plastic measuring bottles. Simultaneously, the same procedure was performed in autoclaves without tissue samples (only $\mathrm{HNO} 3+\mathrm{H} 2 \mathrm{O} 2+$ deionized water), and the resultant solutions were used as control samples.

\section{Instrumentation and methods}

A vertical channel of a nuclear reactor was applied to determine the trace element mass fractions by INAA-LLR. The quartz ampoule with prostate samples and certified reference materials was soldered, positioned in a transport aluminum container, and exposed to a 24-hour neutron irradiation in a vertical channel with a neutron flux of $1.3 \square 1013 \mathrm{n} \square \mathrm{cm}-2 \square \mathrm{s}-1$. Ten days after irradiation samples were reweighed and repacked. The samples were measured for period from 10 to 30 days after irradiation. The duration of measurements was from $20 \mathrm{~min}$ to 10 hours subject to pulse counting rate. The gamma spectrometer used for INAA-LLR included the $100 \mathrm{~cm} 3 \mathrm{Ge}(\mathrm{Li})$ detector and on-line computer-based multichannel analyzer. The spectrometer provided a resolution of $1.9 \mathrm{keV}$ on the $60 \mathrm{Co} 1332 \mathrm{keV}$ line. Other details of the INAALLR analysis were presented in our previous publication [15].

An ICP-MS Thermo-Fisher "X-7” Spectrometer (Thermo Electron, 
USA) was used to determine the content of trace elements by ICP-MS. The element concentrations in aqueous solutions were determined by the quantitative method using multi elemental calibration solutions ICP-MS-68A and ICP-AM-6-A produced by High-Purity Standards (Charleston, SC 29423, USA). Indium was used as an internal standard in all measurements. Information detailing with the ICP-MS method used was presented in our previous publication [18].

\section{Certified reference materials}

For quality control, ten subsamples of the certified reference materials (CRM) IAEA H-4 Animal muscle and IAEA HH-1 Human hair from the International Atomic Energy Agency (IAEA), and also five sub-samples INCT-SBF-4 Soya Bean Flour, INCTTL-1 Tea Leaves and INCT-MPH-2 Mixed Polish Herbs from the Institute of Nuclear Chemistry and Technology (INCT, Warszawa, Poland) were analyzed simultaneously with the investigated prostate tissue samples. All samples of CRMs were treated in the same way as the prostate samples. Detailed results of this quality assurance program were presented in earlier publications $[15,18]$.

\section{Computer programs and statistic}

A dedicated computer program for INAA mode optimization was used [76]. All prostate samples for INAA-LLR were prepared in duplicate and mean values of trace element contents were used in final calculation. For elements investigated by both INAA-LLR and ICP-MS methods the mean of all results was used. Using the Microsoft Office Excel software Co/trace element contents for each trace element in every sample were calculated. Then arithmetic mean $\square$ standard error of mean was calculated for trace element mass fraction and for ratios of $\mathrm{Co} /$ trace element mass fraction in normal, benign hyperplastic and cancerous prostate. The difference in the results between $\mathrm{BPH}$ and $\mathrm{N}, \mathrm{PCa}$ and $\mathrm{N}$, as well as $\mathrm{PCa}$ and BPH was evaluated by parametric Student's t-test and nonparametric Wilcoxon-Mann-Whitney U-test. Values of $\mathrm{p}<0.05$ were considered to be statistically significant. For the construction of "individual data sets for Co/trace element mass fraction ratios in normal, benign hypertrophic and cancerous prostate" diagrams the Microsoft Office Excel software was also used.

\section{Results}

Table 1 represents mean values $\square$ standard error of mean $(\mathrm{M} \square \mathrm{SEM})$ of the $\mathrm{Ag}, \mathrm{Al}, \mathrm{Au}, \mathrm{B}, \mathrm{Be}, \mathrm{Bi}, \mathrm{Br}, \mathrm{Cd}, \mathrm{Ce}, \mathrm{Co}, \mathrm{Cr}, \mathrm{Cs}$, Dy, Er, Fe, Gd, Hg, Ho, La, Li, Mn, Mo, Nb, Nd, Ni, Pb, Pr, Rb, $\mathrm{Sb}, \mathrm{Sc}, \mathrm{Se}, \mathrm{Sm}, \mathrm{Sn}, \mathrm{Tb}, \mathrm{Th}, \mathrm{Ti}, \mathrm{Tl}, \mathrm{Tm}, \mathrm{U}, \mathrm{Y}, \mathrm{Yb}, \mathrm{Zn}$ and $\mathrm{Zr}$ mass fraction in normal, benign hypertrophic and cancerous prostate.

Table 2 depicts mean values $\square$ standard error of mean (M $\square$ SEM) of the ratio to $\mathrm{Co}$ of $\mathrm{Ag}, \mathrm{Al}, \mathrm{Au}, \mathrm{B}, \mathrm{Be}, \mathrm{Bi}, \mathrm{Br}, \mathrm{Cd}, \mathrm{Ce}, \mathrm{Cr}, \mathrm{Cs}, \mathrm{Dy}$, Er, Fe, Gd, Hg, Ho, La, Li, Mn, Mo, Nb, Nd, Ni, Pb, Pr, Rb, Sb, Sc, $\mathrm{Se}, \mathrm{Sm}, \mathrm{Sn}, \mathrm{Tb}, \mathrm{Th}, \mathrm{Ti}, \mathrm{Tl}, \mathrm{Tm}, \mathrm{U}, \mathrm{Y}, \mathrm{Yb}, \mathrm{Zn}$, and $\mathrm{Zr}$ mass fraction in normal, benign hypertrophic and cancerous prostate.

The ratios of means and the difference between mean values of the $\mathrm{Co} /$ trace element mass fraction ratios in normal, benign hypertrophic and cancerous prostate are presented in Table 3 .
Individual data sets for $\mathrm{Co} / \mathrm{Ag}, \mathrm{Co} / \mathrm{Al}, \mathrm{Co} / \mathrm{B}, \mathrm{Co} / \mathrm{Bi}, \mathrm{Co} / \mathrm{Li}, \mathrm{Co} /$ $\mathrm{Mn}, \mathrm{Co} / \mathrm{Pr}, \mathrm{Co} / \mathrm{Th}, \mathrm{Co} / \mathrm{Tl}$, and $\mathrm{Co} / \mathrm{Zr}$ mass fraction ratios in all investigated samples of normal, benign hypertrophic and cancerous prostate, respectively, are shown in Figure 1.

Table 4 contains parameters of the importance (sensitivity, specificity and accuracy of $\mathrm{Co} / \mathrm{Ag}, \mathrm{Co} / \mathrm{Al}, \mathrm{Co} / \mathrm{B}, \mathrm{Co} / \mathrm{Bi}, \mathrm{Co} / \mathrm{Li}, \mathrm{Co} /$ $\mathrm{Mn}, \mathrm{Co} / \mathrm{Pr}, \mathrm{Co} / \mathrm{Th}, \mathrm{Co} / \mathrm{Tl}$, and $\mathrm{Co} / \mathrm{Zr}$ mass fraction ratios for the diagnosis of $\mathrm{PCa}$ calculated in this work.

\section{Discussion}

As was shown by us $[14,15,17,18]$, the use of CRM IAEA H-4 Animal muscle, IAEA HH-1 Human hair, INCT-SBF-4 Soya Bean Flour, INCT-TL-1 Tea Leaves, and INCT-MPH-2 Mixed Polish Herbs as certified reference materials for the analysis of samples of prostate tissue can be seen as quite acceptable. Good agreement of the trace element contents in these CRMs, measured by us using INAA-LLR and ICP-MS methods, with the certified data $[14,15,17,18]$ indicates an acceptable accuracy of the results obtained in the present study.

The mean values and standard error of mean $( \pm$ SEM) were calculated for 43 trace element contents including Co (Table 1), as well as for 42 ratios of $\mathrm{Co} /$ trace element mass fractions (Table 2 ). The mass fraction of $\mathrm{Co}$ and other 42 trace elements were measured in all, or a major portion of normal prostate samples. The masses of BPH and PCa samples varied very strong from a few milligrams (sample from needle biopsy material) to $100 \mathrm{mg}$ (sample from resected material). Therefore, in $\mathrm{BPH}$ and $\mathrm{PCa}$ prostates mass fraction ratios of $\mathrm{Co} / \mathrm{Ag}, \mathrm{Co} / \mathrm{Cr}, \mathrm{Co} / \mathrm{Fe}, \mathrm{Co} / \mathrm{Hg}$, $\mathrm{Co} / \mathrm{Rb}, \mathrm{Co} / \mathrm{Sb}, \mathrm{Co} / \mathrm{Sc}, \mathrm{Co} / \mathrm{Se}$, and $\mathrm{Co} / \mathrm{Zn}$ were measured in all, or a major portion of samples, while ratios to Co of other trace element content were determined in 21 samples (11 BPH and 10 PCa samples, respectively).

From Table 3, it is observed that in benign hypertrophic tissues the $\mathrm{Co} / \mathrm{Ag}, \mathrm{Co} / \mathrm{Au}, \mathrm{Co} / \mathrm{B}, \mathrm{Co} / \mathrm{Be}, \mathrm{Co} / \mathrm{Br}, \mathrm{Co} / \mathrm{Cd}, \mathrm{Co} / \mathrm{Fe}, \mathrm{Co} / \mathrm{La}, \mathrm{Co} /$ $\mathrm{Li}, \mathrm{Co} / \mathrm{Nb}, \mathrm{Co} / \mathrm{Ni}, \mathrm{Co} / \mathrm{Pb}, \mathrm{Co} / \mathrm{Sc}, \mathrm{Co} / \mathrm{Se}, \mathrm{Co} / \mathrm{Th}, \mathrm{Co} / \mathrm{Ti}, \mathrm{Co} / \mathrm{Tl}, \mathrm{Co} /$ $\mathrm{Yb}, \mathrm{Co} / \mathrm{Zn}$, and $\mathrm{Co} / \mathrm{Zr}$ mass fraction ratios not differ from normal levels, but the mass fraction ratios of $\mathrm{Co} / \mathrm{Al}, \mathrm{Co} / \mathrm{Ce}, \mathrm{Co} / \mathrm{Cs}, \mathrm{Co} /$ $\mathrm{Dy}, \mathrm{Co} / \mathrm{Er}, \mathrm{Co} / \mathrm{Gd}, \mathrm{Co} / \mathrm{Ho}, \mathrm{Co} / \mathrm{Mn}, \mathrm{Co} / \mathrm{Mo}, \mathrm{Co} / \mathrm{Nd}, \mathrm{Co} / \mathrm{Pr}, \mathrm{Co} / \mathrm{Rb}$, $\mathrm{Co} / \mathrm{Sm}, \mathrm{Co} / \mathrm{Sn}, \mathrm{Co} / \mathrm{Tb}, \mathrm{Co} / \mathrm{Tm}, \mathrm{Co} / \mathrm{U}$, and $\mathrm{Co} / \mathrm{Y}$ are higher, while the mass fraction ratios of $\mathrm{Co} / \mathrm{Bi}, \mathrm{Co} / \mathrm{Cr}, \mathrm{Co} / \mathrm{Hg}$, and $\mathrm{Co} / \mathrm{Sb}$ are significantly lower. In cancerous tissue the all $\mathrm{Co} /$ trace element mass fraction ratios investigated in the study are significantly lower, than in $\mathrm{BPH}$ and normal prostate, with the exception of $\mathrm{Co} /$ $\mathrm{Cd}, \mathrm{Co} / \mathrm{Cs}, \mathrm{Co} / \mathrm{Fe}, \mathrm{Co} / \mathrm{Hg}, \mathrm{Co} / \mathrm{Mo}, \mathrm{Co} / \mathrm{Nb}, \mathrm{Co} / \mathrm{Rb}, \mathrm{Co} / \mathrm{Sc}, \mathrm{Co} / \mathrm{Se}$, $\mathrm{Co} / \mathrm{Yb}$, and $\mathrm{Co} / \mathrm{Zn}$ ratios.

Analysis of the mass fraction ratios for trace element in prostate tissue could become a powerful diagnostic tool. To a large extent, the resumption of the search for new methods for early diagnosis of $\mathrm{PCa}$ was due to experience gained in a critical assessment of the limited capacity of the prostate specific antigen (PSA) serum test $[77,78]$. In addition to the PSA serum test and morphological study of needle-biopsy cores of the prostate, the development of other highly precise testing methods seems to be very useful. Experimental conditions of the present study were approximated 
to the hospital conditions as closely as possible. In BPH and PCa cases we analyzed a part of the material obtained from a puncture transrectal biopsy of the indurated site in the prostate. Therefore, our data allow us to evaluate adequately the importance of $\mathrm{Co} /$ trace element mass fraction ratios for the diagnosis of $\mathrm{PCa}$. As is evident from Table 3 and, particularly, from individual data sets of ratios (Fig. 1), the $\mathrm{Co} / \mathrm{Ag}, \mathrm{Co} / \mathrm{Al}, \mathrm{Co} / \mathrm{B}, \mathrm{Co} / \mathrm{Bi}, \mathrm{Co} / \mathrm{Li}, \mathrm{Co} / \mathrm{Mn}, \mathrm{Co} /$ $\mathrm{Pr}, \mathrm{Co} / \mathrm{Th}, \mathrm{Co} / \mathrm{Tl}$, and $\mathrm{Co} / \mathrm{Zr}$ mass fraction ratios are potentially the most informative test for a differential diagnosis. For example, if 0.5 is the value of $\mathrm{Co} / \mathrm{Ag}$ mass fraction ratio assumed to be the upper limit for $\mathrm{PCa}$ (Fig. 1) and an estimation is made for "PCa or intact and BPH tissue", the following values are obtained:

Sensitivity $=\{$ True Positives $(\mathrm{TP}) /[\mathrm{TP}+$ False Negatives $(\mathrm{FN})]\}$ $\cdot 100 \%=90 \pm 6 \%$;

Specificity $=\{$ True Negatives $(\mathrm{TN}) /[\mathrm{TN}+$ False Positives (FP) $]\}$ $\cdot 100 \%=89 \pm 5 \%$.

Accuracy $=[(\mathrm{TP}+\mathrm{TN}) /(\mathrm{TP}+\mathrm{FP}+\mathrm{TN}+\mathrm{FN})] \cdot 100 \%=93 \pm 3 \%$.

The number of people (samples) examined was taken into account for calculation of confidence intervals [79]. In other words, if Co/ $\mathrm{Ag}$ mass fraction ratio in a prostate biopsy sample is lower 0.5 , one could diagnose a malignant tumor with an accuracy $93 \pm 3 \%$. Thus, using the $\mathrm{Co} / \mathrm{Ag}$ mass fraction ratio-test makes it possible to diagnose cancer in $90 \pm 6 \%$ cases (sensitivity). The same way parameters of the importance (sensitivity, specificity and accuracy) of for $\mathrm{Co} / \mathrm{Al}, \mathrm{Co} / \mathrm{B}, \mathrm{Co} / \mathrm{Bi}, \mathrm{Co} / \mathrm{Li}, \mathrm{Co} / \mathrm{Mn}, \mathrm{Co} / \mathrm{Pr}, \mathrm{Co} / \mathrm{Th}, \mathrm{Co} / \mathrm{Tl}$, and $\mathrm{Co} / \mathrm{Zr}$ mass fraction ratios for the diagnosis of $\mathrm{PCa}$ were also calculated (Table 4).

\section{Conclusion}

The combination of nondestructive INAA-LLR and destructive ICP-MS methods is satisfactory analytical tool for the precise determination of 43 trace element mass fractions in the tissue samples of normal, BPH and carcinomatous prostate glands. The sequential application of these methods allowed precise quantitative determinations of mean mass fraction of $\mathrm{Ag}, \mathrm{Al}, \mathrm{Au}$, B, Be, Bi, Br, Cd, Ce, Co, Cr, Cs, Dy, Er, Fe, Gd, Hg, Ho, La, Li, Mn, Mo, Nb, Nd, Ni, Pb, Pr, Rb, Sb, Sc, Se, Sm, Sn, Tb, Th, Ti, Tl, $\mathrm{Tm}, \mathrm{U}, \mathrm{Y}, \mathrm{Yb}, \mathrm{Zn}$ and $\mathrm{Zr}$. It was observed that the ratio to $\mathrm{Co}$ of $\mathrm{Ag}$, $\mathrm{Al}, \mathrm{Au}, \mathrm{B}, \mathrm{Be}, \mathrm{Bi}, \mathrm{Br}, \mathrm{Ce}, \mathrm{Cr}$, Dy, Er, Gd, Ho, La, Li, Mn, Nd, Ni, $\mathrm{Pb}, \mathrm{Pr}, \mathrm{Sb}, \mathrm{Sm}, \mathrm{Sn}, \mathrm{Tb}, \mathrm{Th}, \mathrm{Ti}, \mathrm{Tl}, \mathrm{U}, \mathrm{Y}$, and $\mathrm{Zr}$ mass fraction were significantly lower in cancerous tissues than in normal and $\mathrm{BPH}$ prostate. Finally, we propose to use the $\mathrm{Co} / \mathrm{Ag}, \mathrm{Co} / \mathrm{Al}, \mathrm{Co} / \mathrm{B}, \mathrm{Co} /$ $\mathrm{Bi}, \mathrm{Co} / \mathrm{Li}, \mathrm{Co} / \mathrm{Mn}, \mathrm{Co} / \mathrm{Pr}, \mathrm{Co} / \mathrm{Th}, \mathrm{Co} / \mathrm{Tl}$, and $\mathrm{Co} / \mathrm{Zr}$ mass fraction ratios in a needle-biopsy core as an accurate tool to diagnose prostate cancer. Further studies on larger number of samples are required to confirm our findings and to investigate the impact of the trace element relationships on prostate cancer etiology.

\section{Acknowledgements}

We are grateful to Dr. Tatyana Sviridova, Medical Radiological Research Center, Obninsk, and to the late Prof. A.A. Zhavoronkov, Institute of Human Morphology, Russian Academy of Medical Sciences, Moscow, for supplying prostate samples. We are also grateful to Dr. Karandaschev V., Dr. Nosenko S., and Moskvina
I., Institute of Microelectronics Technology and High Purity Materials, Chernogolovka, Russia, for their help in ICP-MS analysis.

\section{Competing interests}

All other authors declare no competing interests.

\section{References}

1. Roehrborn C, McConnell J (2002) Etiology, pathophysiology, epidemiology and natural history of benign prostatic hyperplasia. In: Walsh P, Retik A, Vaughan E, Wein A, editors. Campbell's Urology (8th edn). Saunders, Philadelphia: 1297-1336.

2. Lepor H (2005) Pathophysiology of benign prostatic hyperplasia in the aging male population. Rev Urol 7(Suppl 4): S3-S12.

3. Oliver SE, Gunnell D, Donovan JL (2000) Comparison of trends in prostate-cancer mortality in England and Wales and the USA. Lancet 355: 1788-1789.

4. Kumar RJ, Barqawi AB, Crawford ED (2004) Epidemiology of prostate cancer. Business Briefing: US Oncology Review: 1-6.

5. Maddams J, Brewster D, Gavin A, Steward J, Elliott J, et al. (2009) Cancer prevalence in the United Kingdom: estimates for 2008. Br J Cancer 101(3): 541-547.

6. Lutz JM, Francisci S, Mugno E, Usel M, Pompe-Kirn V, et al. (2003) Cancer prevalence in Central Europe: the EUROPREVAL Study. Ann Oncol 14(2): 313-322.

7. Möller T, Anderson H, Aareleid T, Hakulinen T, Storm H, et al. (2003) Cancer prevalence in Northern Europe: the EUROPREVAL study. Ann Oncol 14(6): 946-957.

8. De Angelis R, Grande E, Inghelmann R, Francisci S, Micheli A, et al. (2007) Cancer prevalence estimates in Italy from 1970 to 2010. Tumori 93(4): 392-397.

9. Waalkes MP, Rehm S (1994) Cadmium and prostate cancer. J Toxicol Environ Health 43: 251-269.

10. Zaichick V, Zaichick S (1999) Role of zinc in prostate cancerogenesis. In: Anke $M$, et al., editors. Mengen und Spurenelemente. 19. Arbeitstagung. Friedrich-Schiller-Universitat. Jena: 104-115.

11. Platz EA, Helzlsouer KJ (2001) Selenium, zinc, and prostate cancer. Epidemiol Rev 23: 93-101.

12. Zaichick V (2004) INAA and EDXRF applications in the age dynamics assessment of $\mathrm{Zn}$ content and distribution in the normal human prostate. J Radioanal Nucl Chem 262(1): 229-234.

13. Gray MA, Centeno JA, Slaney DP, Ejnik JW, Todorov T, et al. (2005) Environmental exposure to trace elements and prostate cancer in three New Zealand ethnic groups. Int J Environ Res Public Health 2: 374-384.

14. Zaichick S, Zaichick V (2011) INAA application in the age dynamics assessment of $\mathrm{Br}, \mathrm{Ca}, \mathrm{Cl}, \mathrm{K}, \mathrm{Mg}, \mathrm{Mn}$, and $\mathrm{Na}$ content in the normal human prostate. J Radioanal Nucl Chem 288(1): 197- 
202.

15. Zaichick S, Zaichick V (2011) The effect of age on Ag, Co, $\mathrm{Cr}, \mathrm{Fe}, \mathrm{Hg}, \mathrm{Sb}, \mathrm{Sc}, \mathrm{Se}$, and $\mathrm{Zn}$ contents in intact human prostate investigated by neutron activation analysis. Appl Radiat Isot 69: 827-833.

16. Zaichick S, Zaichick V (2011) The Br, Fe, Rb, Sr, and Zn content and interrelation in intact and morphologic normal prostate tissue of adult men investigated by energy dispersive X-ray fluorescent analysis. X-Ray Spectrom 40(6): 464-469.

17. Zaichick V, Nosenko S, Moskvina I (2012) The effect of age on 12 chemical element contents in intact prostate of adult men investigated by inductively coupled plasma atomic emission spectrometry. Biol Trace Elem Res 147(1): 49-58.

18. Zaichick S, Zaichick V, Nosenko S, Moskvina I (2012) Mass Fractions of 52 Trace Elements and Zinc Trace Element Content Ratios in Intact Human Prostates Investigated by Inductively Coupled Plasma Mass Spectrometry. Biol Trace Elem Res 149(2): 171-183.

19. Zaichick V, Zaichick S (2014) Age-related histological and zinc content changes in adult nonhyperplastic prostate glands. Age 36(1): 167-181.

20. Zaichick V, Zaichick S (2014) INAA application in the assessment of chemical element mass fractions in adult and geriatric prostate glands. Appl Radiat Isot 90: 62-73.

21. Zaichick V, Zaichick S (2014) Determination of trace elements in adults and geriatric prostate combining neutron activation with inductively coupled plasma atomic emission spectrometry. Open Journal of Biochemistry 1(2): 16-33.

22. Zaichick V, Zaichick S (2014) Use of INAA and ICP-MS for the assessment of trace element mass fractions in adult and geriatric prostate. J Radioanal Nucl Chem 301(2): 383-397.

23. Zaichick V (2015) The variation with age of 67 macro- and microelement contents in nonhyperplastic prostate glands of adult and elderly males investigated by nuclear analytical and related methods. Biol Trace Elem Res 168(1): 44-60.

24. Zaichick V, Zaichick S (2015) Dietary intake of minerals and prostate cancer: insights into problem based on the chemical element contents in the prostate gland. J Aging Res Clin Practice 4(3): 164-171.

25. Zaichick V, Zaichick S (2015) Global contamination from uranium: insights into problem based on the uranium content in the human prostate gland. J Environ Health Sci 1(4): 1-5.

26. Zaichick V, Zaichick S (2016) Variations in concentration and distribution of several androgen-dependent and -independent trace elements in nonhyperplastic prostate gland tissue throughout adulthood. J Androl Gynaecol 4(1): 1-10.

27. Zaichick V, Zaichick S (2016) Age-related changes in concentration and histological distribution of $\mathrm{Br}, \mathrm{Ca}, \mathrm{Cl}, \mathrm{K}, \mathrm{Mg}$, $\mathrm{Mn}$, and $\mathrm{Na}$ in nonhyperplastic prostate of adults. European
Journal of Biology and Medical Science Research 4(2): 31-48.

28. Zaichick V., Zaichick S (2016) Variations in concentration and histological distribution of $\mathrm{Ag}, \mathrm{Co}, \mathrm{Cr}, \mathrm{Fe}, \mathrm{Hg}, \mathrm{Rb}, \mathrm{Sb}, \mathrm{Sc}, \mathrm{Se}$, and $\mathrm{Zn}$ in nonhyperplastic prostate gland throughout adulthood. Jacobs Journal of Cell and Molecular Biology 2(1): 011.

29. Zaichick V, Zaichick S (2016) Age-related changes in concentration and histological distribution of 54 trace elements in nonhyperplastic prostate of adults. Int Arch Urol Complic 2(2):019

30. Zaichick V (2006) Medical elementology as a new scientific discipline. J Radioanal Nucl Chem 269: 303-309.

31. Stitch SR (1957) Trace elements in human tissue. I. A semiquantitative spectrographic survey. Biochem J 67: 97-103.

32. Tipton IH, Cook MJ (1963) Trace elements in human tissue. Part II. Adult subjects from the United States. Health Phys 9: 103145.

33. Györkey F, Min K-W, Huff JA, Györkey P (1967) Zinc and magnesium in human prostate gland: normal, hyperplastic, and neoplastic. Cancer Res 27: 1349-1353.

34. Sangen H (1967) The influence of the trace metals upon the aconitase activity in human prostate glands. Jap J Urol 58: 11461159.

35. Schneider H-J, Anke M, Holm W (1970) The inorganic components of testicle, epididymis, seminal vesicle, prostate and ejaculate of young men. Int Urol Nephrol 2(4): 419-427.

36. Hienzsch E, Schneider H-J, Anke M (1970) Vergleichende Untersuchungen zum Mengen- und Spurenelementgehalt der normalen Prostata, des Prostataadenoms und des Prostatakarzinoms. Zeitschrift für Urologie und Nephrologie 63: 543-546.

37. Soman SD, Joseph KT, Raut SJ, Mulay GD, Parameswaran M, et al. (1970) Studies of major and trace element content in human tissues. Health Phys 19: 641-656.

38. Forssen A (1972) Inorganic elements in the human body. I. occurrence of $\mathrm{Ba}, \mathrm{Br}, \mathrm{Ca}, \mathrm{Cd}, \mathrm{Cs}, \mathrm{Cu}, \mathrm{K}, \mathrm{Mn}, \mathrm{Ni}, \mathrm{Sn}, \mathrm{Sr}, \mathrm{Y}$ and $\mathrm{Zn}$ in the human body. Annales medicinae Experimentalis et Biologie (Finland) 50: 99-162.

39. Dhar NK, Goel TC, Dube PC, Chowdhury AR, Kar AB (1973) Distribution and concentration of zinc in the subcellular fractions of benign hyperplastic and malignant neoplastic human prostate. Exp Mol Pathol 19: 139-142.

40. Jafa A, Mahendra NM, Chowdhury AR, Kamboj VP (1980) Trace elements in prostatic tissue and plasma in prostatic diseases of man. Indian J Cancer 17: 34-37.

41. Marezynska A, Kulpa J, Lenko J (1983) The Concentration of zimc in relation to fundamental elements in the diseases human prostate. Int Urol Nephrol 15: 257-265.

42. Hienzsch E, Schneider H-J, Anke M (1991) Vergleichende Untersuchungen zum Mengen- und Spurenelementgehalt der normalen Prostata, des Prostataadenoms und des Prostatakarzinoms. 
Z Urol Nephrol 63(7): 543-546.

43. Picurelli L, Olcina PV, Roig MD, Ferrer J (1991) Determination of $\mathrm{Fe}, \mathrm{Mg}, \mathrm{Cu}$, and $\mathrm{Zn}$ in normal and pathological prostatic tissue. Actas Urol Esp 15: 344-350.

44. Zaichick V, Sviridova T, Zaichick S (1997) Zinc in human prostate gland: normal, hyperplastic and cancerous. Int Urol Nephrol 29(5): 565-574.

45. Galván-Bobadilla AI, García-Escamilla RM, Gutiérrez-García N, Mendoza-Magaña ML, Rosiles-Martínez R (2005) Cadmium and zinc concentrations in prostate cancer and benign prostate hyperplasia. Rev Latinoamer Patol Clin 52(2): 109-117.

46. Yaman M, Atici D, Bakirdere S, Akdeniz I (2005) Comparison of trace metal concentrations in malignant and benign human prostate. J Med Chem 48(2): 630-634.

47. Kwiatek WM, Banas A, Banas K, Podgorczyk M, Dyduch G, et al. (2006) Distinguishing prostate cancer from hyperplasia. Acta Physica Polonica 109(3): 377-381.

48. Guntupalli JNR, Padala S, Gummuluri AVRM, Muktineni RK, Byreddy SR, et al. (2007) Trace elemental analysis of normal, benign hypertrophic and cancerous tissues of the prostate gland using the particle-induced X-ray emission technique. Eur J Cancer Prev 16(2): 108-115.

49. Tohno S, Kobayashi M, Shimizu H, Tohno Y, Suwannahoy P, et al. (2009) Age-related changes of the concentrations of select elements in the prostates of Japanese. Biol Trace Elem Res 127: 211-227.

50. Kiziler AR, Aydemir B, Guzel S., Alici B, Ataus S, et al. (2010) May the level and ratio changes of trace elements be utilized in identification of disease progression and grade in prostatic cancer? Trace Elements and Electrolytes 27(2): 65-72.

51. Zaichick S, Zaichick V (2010) Method and portable facility for energy-dispersive X-ray fluorescent analysis of zinc content in needle-biopsy specimens of prostate. X-Ray Spectrom 39: 83-89.

52. Zaichick S, Zaichick V (2012) Trace elements of normal, benign hypertrophic and cancerous tissues of the human prostate gland investigated by neutron activation analysis. Appl Radiat Isot 70: 81-87.

53. Zaichick V, Zaichick S (2013) The effect of age on $\mathrm{Br}, \mathrm{Ca}, \mathrm{Cl}$, $\mathrm{K}, \mathrm{Mg}, \mathrm{Mn}$, and $\mathrm{Na}$ mass fraction in pediatric and young adult prostate glands investigated by neutron activation analysis. Appl Radiat Isot 82: 145-151.

54. Zaichick V, Zaichick S (2013) NAA-SLR and ICP-AES Application in the assessment of mass fraction of 19 chemical elements in pediatric and young adult prostate glands. Biol Trace Elem Res 156(1): 357-366.

55. Leitão RG, Palumbo A, Souza PAVR, Pereira GR, Canellas CGL, et al. (2014) Elemental concentration analysis in prostate tissues using total reflection X-ray fluorescence. Radiation Physics and Chemistry 95: 62-64.
56. Zaichick S, Zaichick V (2014) EDXRF determination of trace element contents in benign prostatic hypertrophic tissue. In: Fundamental Interactions and Neutrons, Neutron Spectroscopy, Nuclear Structure, Ultracold Neutrons, Related Topics. Joint Institute for Nuclear Research, Dubna (Russia): 311-316.

57. Denoyer D, Clatworthy SAS, Masaldan S, Meggyesy PM, Cater MA (2015) Heterogeneous Copper Concentrations in Cancerous Human Prostate Tissues. Prostate 75: 1510-1517.

58. Zaichick S, Zaichick V (2015) Prostatic Tissue Level of some Androgen Dependent and Independent Trace Elements in Patients with Benign Prostatic Hyperplasia. Androl Gynecol: Curr Res 3:3.

59. Singh BP, Dwivedi S, Dhakad U, Murthy RC, Choubey VK, et al. (2016) Status and Interrelationship of Zinc, Copper, Iron, Calcium and Selenium in Prostate Cancer. Indian J Clin Biochem 31(1): 50-56.

60. Zaichick V, Zaichick S (2016) Trace element contents in adenocarcinoma of human prostate investigated by energy dispersive X-ray fluorescent analysis. Journal of Adenocarcinoma 1(1): $1-7$.

61. Zaichick V, Zaichick S (2016) The Bromine, Calcium, Potassium, Magnesium, Manganese, and Sodium Contents in Adenocarcinoma of Human Prostate Gland. J Hematology and Oncology Research 2(2): 1-12.

62. Zaichick V, Zaichick S (2016) Trace element contents in adenocarcinoma of the human prostate gland investigated by neutron activation analysis. Cancer Research \& Oncology 1(1): $1-10$.

63. Zaichick V, Zaichick S (2016) Prostatic tissue levels of 43 trace elements in patients with prostate adenocarcinoma. Cancer and Clinical Oncology 5(1): 79-94.

64. Zaichick V, Zaichick S (2016) Prostatic tissue level of some major and trace elements in patients with BPH. Jacobs Journal of Nephrology and Urology 3(1): 025.

65. Zaichick V, Zaichick S (2016) Levels of 43 Trace Elements in Hyperplastic Prostate Tissues. British Journal of Medicine and Medical Research 15(2): 1-12.

66. Zaichick V, Zaichick S (2016) Chemical elemental content / Calcium ratios in tissues of human hyperplastic prostate gland. Journal of Applied Life Sciences International 4(4): 1-11.

67. Zaichick V, Zaichick S (2016) Distinguishing malignant from benign prostate using $\mathrm{Br}, \mathrm{Ca}, \mathrm{K}, \mathrm{Mg}, \mathrm{Mn}$, and $\mathrm{Na}$ content in prostatic tissue. Integrative Molecular Medicine 3(3): 733-738.

68. Zaichick V, Zaichick S (2016) Distinguishing malignant from benign prostate using content of 17 chemical elements in prostatic tissue. Integr Cancer Sci Therap 3(5): 579-587.

69. Rossmann M, Zaichick S, Zaichick V (2016) Distinguishing malignant from benign prostate tumors using $\mathrm{Br}, \mathrm{Fe}, \mathrm{Rb}, \mathrm{Sr}$, and $\mathrm{Zn}$ content in prostatic tissue. The Journal Prostate Cancer - Clinics in Oncology 1: Article 1054. 
70. Zaichick V, Zaichick S (2017) Ratios of Zn/trace element contents in prostate gland as carcinoma's markers. Cancer Rep Rev 1(1): 1-7.

71. Zaichick V (1997) Sampling, sample storage and preparation of biomaterials for INAA in clinical medicine, occupational and environmental health. In: Harmonization of Health-Related Environmental Measurements Using Nuclear and Isotopic Techniques. IAEA, Vienna: 123-133.

72. Zaichick V, Zaichick S (1996) Instrumental effect on the contamination of biomedical samples in the course of sampling. The Journal of Analytical Chemistry 51(12): 1200-1205.

73. Zaichick V, Zaichick S (1997) A search for losses of chemical elements during freeze-drying of biological materials. J Radioanal Nucl Chem 218(2): 249-253.

74. Zaichick V (2004) Losses of chemical elements in biological samples under the dry aching process. Trace Elements in Medicine 5(3): 17-22.
75. Zaichick V (1995) Application of synthetic reference materials in the Medical Radiological Research Centre. Fresenius J Anal Chem 352: 219-223.

76. Korelo AM, Zaichick V (1993) Software to optimize the multielement INAA of medical and environmental samples. In: Activation Analysis in Environment Protection. Joint Institute for Nuclear Research, Dubna, Russia: 326-332.

77. Catalona WJ (1996) Clinical utility of measurements of free and total prostate-specific antigen (PSA): A review. Prostate 7: 64-69.

78. Hjertholm P, Fenger-Gron M, Vestergaard M, Christensen MB, Borre M, et al. (2015) Variation in general practice prostate-specific antigen testing and prostate cancer outcomes: An ecological study. Int. J. Cancer 136: 435-442.

79. Genes VS (1967) Simple methods for cybernetic data treatment of diagnostic and physiological studies. Nauka, Moscow. 